\title{
Molecular discrimination among taxa of Petunia axillaris complex and $P$. integrifolia complex based on PolA1 sequence analysis
}

\author{
Xinwang Zhang ${ }^{1)}$, Hiroko Takahashi' ${ }^{1)}$, Ikuo Nakamura ${ }^{* 2)}$ and Masahiro Mii' ${ }^{2)}$ \\ 1) Graduate School of Science and Technology, Chiba University, 1-33 Yayoi, Inage, Chiba, Chiba 263-8522, Japan \\ 2) Faculty of Horticulture, Chiba University, 648 Matsudo, Matsudo, Chiba 271-8510, Japan
}

\begin{abstract}
Petunia axillaris complex and $P$. integrifolia complex consist of three subspecies (ssp. axillaris, ssp. parodii and ssp. subandina) and two species ( $P$. integrifolia and $P$. inflata), respectively. Since these taxa within each complex can only be distinguished by the flower morphology, it would be useful to discriminate them by DNA markers. In this study, we sequenced the 19th intron and the 20th exon of the PolAl gene, a single gene encoding the largest subunit of RNA polymerase I, and showed clear differences between $P$. axillaris complex and $P$. integrifolia complex, and also among all the taxa within each complex. These sequence variations will be promising to develop PCR-based markers to discriminate taxa within $P$. axillaris complex and P. integrifolia complex.
\end{abstract}

Key Words: PolA1, Petunia, Solanaceae, DNA marker, discrimination, sequence analysis.

\section{Introduction}

The genus Petunia (Solanaceae) was originally established by Jussieu (1803) and occurs primarily in subtropical and temperate South America. Later, Wijsman (1990) divided the genus into two genera, Petunia $(2 n=14)$ and Calibrachoa $(2 n=18)$. The genus Petunia is considered to comprise 19 taxa (Watanabe et al. 1999, Mishiba et al. 2000), which were classified into four groups (A, B, C and D) by Ando et al. (1999) according to their constituents and contents of major anthocyanins and their difference in pigment biosynthesis patterns with respect to the presence of blocking mechanisms or inhibitors for hydroxylation, glucosylation and acylation reactions.

Cultivars of garden petunias (Petunia hybrida Vilm.) have been bred since the early 1830s (Paxton 1836). The progenitors of garden petunias have been presumed to be of two species groups, P. axillaris complex with a white flower, and $P$. integrifolia complex with a purple flower (Ferguson and Ottley 1932, Sink 1975), which were classified into A group and D group, respectively by Ando et al. (1999). However, there is no clear evidence to show which taxa were actually used as genetic donors for garden petunias. After a long controversial history of classification of $P$. axillaris (Steere 1931, Ferguson and Ottley 1932, Cabrera 1977, Wijsman 1982), Ando (1996) revealed that the P. axillaris complex consists of three subspecies, ssp. axillaris, ssp. parodii and ssp. subandina, which are morphologically similar to each other except for the flower characters: ssp.

Communicated by H. Yamagishi

Received October 15, 2007. Accepted January 16, 2008.

*Corresponding author (e-mail: inakamur@faculty.chiba-u.jp) axillaris having didynamous stamens, two long, two medium and one short, a short corolla tube, and rounded corolla lobes; ssp. subandina having the same didynamous stamens as ssp. axillaris, a long corolla tube, and acute corolla lobes; ssp. parodii having four long stamens of equal length and a short one, a long slender corolla tube, and acute corolla lobes. Since these three subspecies are morphologically similar to each other except for the flower characters, it is difficult to identify subspecies of $P$. axillaris before blooming, which has caused a long history of confusion in recognizing infraspecific taxa in P. axillaris complex (Steere 1931, Ferguson and Ottley 1932, Cabrera 1977, Wijsman 1982, Ando 1996).

The classification of $P$. integrifolia complex has also been controversial (Fires 1911, Smith and Downs 1966, Wijsman 1982). Fires (1911) noted that one of the main characters distinguishing $P$. integrifolia and $P$. inflata is the pedicel condition in the fruiting state: the pedicels are deflexed in $P$. integrifolia, whereas inflexed in $P$. inflata. However, Wijsman (1982) discovered that both flower size and pedicel condition were correlated with geographical distribution, and concluded that $P$. integrifolia and $P$. inflata were not distinct species, but were subspecies of a single, broadly defined species. In contrast, Ando et al. (2005) recognized that $P$. integrifolia and $P$. inflata are allopatric species based on their geographically distinct distributions and the statistically significant gaps between morphological measurements in these two taxa. However, because of their close similarity in morphological characters, there have been no distinct qualitative indicators to distinguish them until now.

In the genus Petunia, several molecular studies have been reported to clarify the relationships among the several taxa, such as RFLP analysis of ribosomal DNA (Kabbaj et 
al. 1995), DNA amplification fingerprinting (Cerny et al. 1996), sequence polymorphism in a chalcone synthase intron (Griesbach et al. 2000), and RFLP analysis of chloroplast DNA (Ando et al. 2005). Kulcheski et al. (2006) attempted to analyze 11 taxa of Petunia using combined data of nuclear ribosomal DNA sequences and plastid DNA sequences. However, none of these molecular studies was designed to provide molecular evidence for distinguishing the taxa within P. axillaris and P. integrifolia complexes.

One of the most useful methods for investigating taxonomic and phylogenetic relationships among living organisms of all types is the comparison of particular DNA sequences. Sang (2002) clearly stated that sequences of single or low-copy nuclear genes are particularly helpful to understand inter- and intra-specific relationships of various plant groups. Recently, we found that DNA sequences of the 19th intron and 20th exon of the PolAl gene showed speciesspecific variation in the genus Oryza (Takahashi and Nakamura 2005). The PolA1 gene encodes the largest subunit of RNA polymerases I and presents as a single copy per haploid genome in almost all plants. In the present study, we focused on sequence variability in the PolA1 19th intron and 20th exon to distinguish closely related taxa in $P$. axillaris and $P$. integrifolia complexes, and provide evidence for the usefulness of the PolAl gene as a nuclear marker to discriminate these taxa.

\section{Materials and Methods}

\section{Plant materials}

Seeds of 5 wild Petunia taxa with 2 accessions per taxon were collected from geographically isolated wild localities (Table 1). Plants raised from seeds were grown in a greenhouse, following standard horticultural practices for garden petunias, and used for DNA analysis. As out-group material, a vegetative cultivar 'Million Bell' (MB) of the genus Calibrachoa, which is a closely related genus to Petunia, was obtained from Suntory Flowers Ltd., Japan and cultivated under the same conditions as petunias.

\section{Genomic DNA isolation and PCR amplification}

Genomic DNA was extracted from $c a .0 .5 \mathrm{~g}$ of young leaves of every accession using a modified CTAB method (Lassner et al. 1989). The forward primer, designated 19ex5P (5'-CTCGCTGGACGGGGTGAGATGAATG-3'), and the reverse primer, designated $21 \mathrm{ex} 3 \mathrm{P}\left(5^{\prime}\right.$-ATACTTTC TTTGCAGCTTTTGGG-3'), were designed based on the PolA1 gene (GenBank accession No. NM_125397) of Arabidopsis thaliana and EST (GenBank accession No. BI179110) of potato, respectively. DNA fragments containing 19th intron and 20th exon sequences of the PolA1 gene were amplified by PCR using a pair of $19 \mathrm{ex} 5 \mathrm{P}$ and 21 ex3P primers (Fig. 1).

The reaction mixture of $25 \mu 1$ contained $10-50$ ng of genomic DNA, 1 unit of Ex Taq DNA polymerase (TaKaRa Co., Japan), $2.5 \mu \mathrm{l}$ of $10 \times$ buffer $(100 \mathrm{mM}$ Tris-Cl, $500 \mathrm{mM}$ $\mathrm{KCl}$, and $\left.15 \mathrm{mM} \mathrm{MgCl}_{2}, \mathrm{pH} 8.0\right), 2 \mu \mathrm{l}$ of $2.5 \mathrm{mM}$ dNTPs, $1 \mu \mathrm{l}$

Table 1. Collecting localities and specimen codes of Petunia taxa used in this study

\begin{tabular}{|c|c|c|c|}
\hline Taxon & Code & Location (Country, area) & $\mathrm{DDBJ}^{a}$ \\
\hline \multirow[t]{2}{*}{ P. axillaris ssp. axillaris } & U1 & URUGUAY, Canelones & AB369403 \\
\hline & U157 & URUGUAY, Montevideo & AB369404 \\
\hline \multirow[t]{2}{*}{ P. axillaris ssp. parodii } & $\mathrm{U} 27$ & URUGUAY, Artigas & AB369408 \\
\hline & U298 & URUGUAY, Cerro Largo & AB369407 \\
\hline \multirow[t]{2}{*}{ P. axillaris ssp. subandina } & A 100 & ARGENTINA, Salta & AB369405 \\
\hline & A203 & ARGENTINA, Salta & AB369406 \\
\hline \multirow[t]{2}{*}{ P. intergrifolia } & B294 & BRAZIL, Rio Grande do Sul & AB369411 \\
\hline & U106 & URUGUAY, Río Negro & AB369412 \\
\hline \multirow[t]{2}{*}{ P. inflata } & A7 & ARGENTINA, Misiones & AB369409 \\
\hline & A9 & ARGENTINA, Misiones & AB369410 \\
\hline Calibrachoa & 'Million Bell' & Suntory Flowers Ltd. & AB369413 \\
\hline
\end{tabular}

${ }^{a}$ Accession No. of DDBJ (DNA databank of Japan).

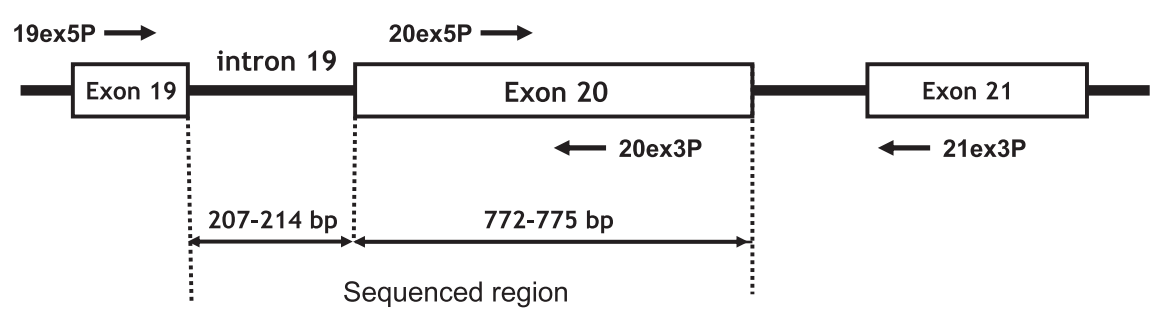

Fig. 1. Schematic representation showing the 3'-region (Exon 19-21) of Petunia PolA1 gene. Primers 19ex5P and 21ex3P (solid arrow) were used to amplify DNA fragment that contained 19th intron (207-214 bp) and 20th exon (772-775 bp). Primers 20ex5P and 20ex3P were used for direct sequencing of the amplified fragments. The sequences indicated by two bidirectional arrows were determined. 
of $2.0 \mu \mathrm{M}$ each primer (19ex $5 \mathrm{P}$ and $21 \mathrm{ex} 3 \mathrm{P})$, and $17.5 \mu \mathrm{l}$ of distilled water. PCR was performed with a condition of 35 cycles of $94^{\circ} \mathrm{C}$ for $1 \mathrm{~min}$ denaturation, $58^{\circ} \mathrm{C}$ for $1 \mathrm{~min}$ annealing, and $72^{\circ} \mathrm{C}$ for 2 min elongation in a PTC200 Thermocycler (MJ Research Co., USA).

\section{Direct Sequencing of PCR products}

The amplified PCR products were subjected to $1.2 \%$ agarose gel electrophoresis, purified with QIAquick PCR Purification Kit (Qiagen Co., USA), and directly sequenced with 19 ex5P or 21 ex3P primer used for PCR amplification by an ABI3100 Automated DNA Sequencer with a Big Dye Terminator Cycle Sequencing Kit (Applied Biosystems Co., USA), and 20ex3P (5'-ACCATCCCCATAATCCATCTCA TC-3') or 20ex5P (5'-TCAAGACAAGCTCGGAATCAGT GG-3') primer was used as an internal sequencing primer. The two internal primers were designed based on the partially determined sequences of PolA1 20th exon of Petunia in this study.

The determined sequences of the 19th intron and the 20th exon of the PolA1 gene were analyzed using a NCBI web-based Blast server (Altschul et al. 1990) and aligned using CLUSTAL W (Thompson et al. 1994) with manual refinement. The aligned sequences were subjected to phylogenetic analysis using Maximum Likelihood software, with bootstrap analysis using 1000 replicates, from the PHYML package (Guindon and Gascuel 2003) of the Pasteur Institute, France (http://bioweb.pasteur.fr/intro-uk.html\#phylo). The Calibrachoa cultivar MB was used as an out-group sample.

The DNA sequences described in this paper have been deposited in the DDBJ DNA database (accession nos. AB369403-AB369413).

\section{Results}

\section{Amplified DNA fragments}

DNA fragments ( $c a .1 .3 \mathrm{~kb}$ in length) containing the 19th intron and 20th exon of the PolAl gene were clearly amplified by PCR using extracted total DNA as templates in 10 accessions of five taxa. Although faint shorter bands ( $c a$. $500 \mathrm{bp}$ ) were also observed, they did not affect the direct sequencing of PCR products. From the length of fragments amplified, it was difficult to discriminate all the taxa examined in the present study by $1.2 \%(\mathrm{w} / \mathrm{v})$ agarose gel electrophoresis (Fig. 2).

\section{Polymorphisms in the sequences of PolA1 19th intron}

The PolA1 19th intron sequences of $P$. axillaris complex, P. integrifolia complex and Calibrachoa MB were $207 \mathrm{bp}, 214 \mathrm{bp}$ and $212 \mathrm{bp}$ in size, respectively. The nucleotide substitution (G/A) at the 19th position and a $7 \mathrm{bp}$ insertion/deletion between 52nd and 58th were uniquely shared by all six accessions of $P$. axillaris (Table 2). Two accessions of $P$. axillaris ssp. parodii showed a nucleotide substitution $\mathrm{A} / \mathrm{G}$ at the 50th position. P. inflata A9 accession

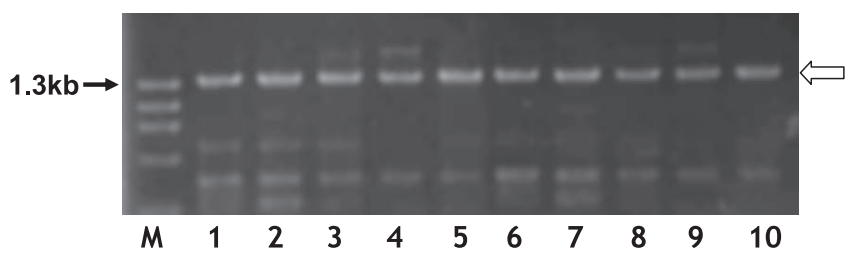

Fig. 2. Electrophoresis pattern of amplified PCR products on a $1.2 \%$ agarose gel. White arrow denotes amplified DNA fragments by PCR with 19ex5P and 21ex3P primers. Size markers ( $\phi X 174 /$ HaeIII) are shown on the left (lane M). Lane 1, P. axillaris ssp. axillaris (U1); lane 2, $P$. axillaris ssp. parodii (U27); lane 3, $P$. axillaris ssp. subandina (A100); lane 4, P. intergrifolia (U106); lane 5, P. inflata (A7); lane 6, P. axillaris ssp. axillaris (U157); lane 7, P. axillaris ssp. parodii (B298); lane 8, P. axillaris ssp. subandina (A203); lane 9, P. intergrifolia (B294); lane 10, P. inflata (A9).

showed an additional heterologous site (A and $\mathrm{T}$ ) at the $81 \mathrm{st}$ position (Table 2).

\section{Polymorphisms in the sequences of the PolA1 20th exon}

The PolA1 20th exon sequences of $P$. axillaris complex, P. integrifolia complex and Calibrachoa MB were $775 \mathrm{bp}, 772 \mathrm{bp}$ and $757 \mathrm{bp}$ in size, respectively. All accessions of the $P$. axillaris complex had a 3 bp longer exon with a 3 base duplication (AAG) than $P$. integrifolia complex at the 612-613th position (Table 2). Moreover, five independent nucleotide substitutions (positions at 298th, 370th, 475th, 479th and 663rd) were found in common in the $P$. axillaris complex. Within the $P$. axillaris complex, ssp. subandina was clearly discriminated from the other two subspecies by two nucleotide substitutions, A vs. G (44th and 514th). P. integrifolia complex shared one common nucleotide substitution $(\mathrm{A} / \mathrm{G})$ at the 627 th position. Within the $P$. integrifolia complex, $P$. integrifolia showed two specific nucleotide substitutions (T and A at 241st and 754th, respectively), while $P$. inflata showed one specific nucleotide substitution (T at 629th).

\section{Phylogenetic tree using PolA1 19th intron and 20th exon sequence variations}

In each three taxa of $P$. axillaris complex, each two accessions showed identical sequences in the 19th intron and 20th exon of the PolA1 gene. The 11 aligned sequences of the gene were analyzed using DNA Maximum Likelihood analysis of PHYML. The majority consensus tree was calculated and drawn by drawtree software (Fig. 3). The obtained phylogenetic tree clearly showed that $P$. integrifolia and $P$. axillaris complexes formed separated clades. A similar tree with the same topology was also obtained by DNA distance and Neighbor-Joining analyses (data not shown). In the $P$. integrifolia complex, two species, inflata and integrifolia, were clearly separated into each group. In the $P$. axillaris complexes, three branches corresponding to each taxon, ssp. parodii, ssp. subandina and ssp. axillaris, were clearly separated, respectively. The Calibrachoa MB 
Table 2. Comparison of variable sites in PolA1 19th intron and 20th exon sequences among species in $P$. integrifolia complex and $P$. axillaris complex

\begin{tabular}{|c|c|c|c|c|c|c|c|c|c|c|c|c|c|c|c|c|c|c|}
\hline \multirow[b]{2}{*}{ Taxon $^{a}$} & \multirow[b]{2}{*}{ Name } & \multicolumn{4}{|c|}{ Positions in 19th intron ${ }^{b}$} & \multicolumn{13}{|c|}{ Positions in 20th exon ${ }^{b}$} \\
\hline & & 19 & 50 & $52-58$ & 81 & 20 & 44 & 241 & 298 & 370 & 475 & 479 & 514 & 612_613 & 627 & 629 & 663 & 754 \\
\hline Calibrachoa & MB & G & A & TGACTTT & A & $\mathrm{T}$ & G & $\mathrm{C}$ & $\mathrm{C}$ & $\mathrm{C}$ & G & A & - & $-\cdots$ & A & G & A & $\mathrm{T}$ \\
\hline \multirow[t]{2}{*}{ P. inflata } & A7 & • & $\cdot$ & $\cdots \cdots \cdots$ & • & $\mathrm{C} / \mathrm{T}$ & $\cdot$ & • & • & - & • & • & $\mathrm{G}$ & -- & G & $\mathrm{T}$ & • & $\cdot$ \\
\hline & A9 & • & $\cdot$ & $\cdots \cdots \cdot$ & $\mathrm{A} / \mathrm{T}$ & $\mathrm{C} / \mathrm{T}$ & $\cdot$ & • & • & • & • & • & $\mathrm{G}$ & -- & G & $\mathrm{T}$ & • & $\cdot$ \\
\hline \multirow[t]{2}{*}{ P. integrifolia } & B294 & - & - & $\ldots \ldots$ & - & - & - & $\mathrm{T}$ & • & - & - & • & $\mathrm{G}$ & $-\ldots$ & G & - & • & $\mathrm{A}$ \\
\hline & U106 & • & • & $\ldots \ldots$ & • & • & • & $\mathrm{T}$ & - & • & $\mathrm{T}$ & • & G & - - - & G & - & - & A \\
\hline \multirow{2}{*}{$\begin{array}{l}\text { P. axillaris ssp. } \\
\text { axillaris }\end{array}$} & U1 & A & • & $-\ldots$ & - & - & - & - & $\mathrm{T}$ & $\mathrm{T}$ & A & G & $\mathrm{G}$ & AAG & • & - & $\mathrm{C}$ & - \\
\hline & U157 & A & • & - _ - - - - & • & - & • & • & $\mathrm{T}$ & $\mathrm{T}$ & A & G & G & AAG & - & • & $\mathrm{C}$ & • \\
\hline \multirow{2}{*}{$\begin{array}{l}\text { P. axillaris ssp. } \\
\text { parodii }\end{array}$} & U27 & A & $\mathrm{G}$ & - - - - - & • & • & • & $\cdot$ & $\mathrm{T}$ & $\mathrm{T}$ & A & G & G & AAG & - & - & $\mathrm{C}$ & - \\
\hline & U298 & A & G & $-\ldots$ & • & $\bullet$ & • & • & $\mathrm{T}$ & $\mathrm{T}$ & A & G & $\mathrm{G}$ & AAG & - & - & $\mathrm{C}$ & • \\
\hline \multirow{2}{*}{$\begin{array}{l}\text { P. axillaris ssp. } \\
\text { subandina }\end{array}$} & A100 & $\mathrm{A}$ & • & - - - - - & - & - & $\mathrm{A}$ & $\cdot$ & $\mathrm{T}$ & $\mathrm{T}$ & A & G & $\mathrm{A}$ & AAG & • & - & $\mathrm{C}$ & • \\
\hline & A203 & A & • & - - - - - - & • & - & A & • & $\mathrm{T}$ & $\mathrm{T}$ & A & G & A & AAG & • & - & $\mathrm{C}$ & • \\
\hline
\end{tabular}

a PolA1 19th intron and 20th exon sequences of Calibrachoa 'Million Bell' (MB) were used as an out-group. The sequences of $P$. integrifolia complex and $P$. axillaris complex were compared with those of Calibrachoa MB and only unique sites of Petunia were shown in this Table.

${ }^{b}$ Number indicates position of the unique site based on the sequence of 19th intron (214bp) or 20th exon (772 bp) in P. inflata A7. Dot indicates the same base with Calibrachoa MB. Dash indicates deletion and underbar between 612 and 613 shows insertion site.

formed a different clade from P. integrifolia and P. axillaris complexes.

\section{Discussion}

In the present study, we successfully sequenced the 19th intron and 20th exon of the PolA1 gene of 5 taxa (2 accessions per taxon) in the genus Petunia; i.e. 3 subspecies in $P$. axillaris complex and 2 species in $P$. integrifolia complex, respectively. Sequence variations clearly identified the two complexes as separate large groups with eight differences (Table 2 and Fig. 3), showing large disparity between them in accordance with A and D groups classified on the basis of the analysis of flower color (Ando et al. 1999). Each corresponding taxon within these complexes was also identified with 1-3 differences. Between two species of the $P$. integrifolia complex, $P$. integrifolia and $P$. inflata, three unique nucleotide substitutions were found in PolA1 20th exon. On the other hand, within the $P$. axillaris complex, ssp. parodii has 1 unique nucleotide substitution in PolA1 19th intron, whereas ssp. subandina has 2 unique nucleotide substitutions in PolA1 20th exon (Table 2). Thus, the present study clearly showed the usefulness of the sequence of the 19th intron and 20th exon of the PolA1 gene.

The variations found in this study would be useful to develop DNA markers such as single nucleotide polymorphisms (SNPs) or sequence-characterized amplified region (SCAR) markers for early discrimination of the taxa before blooming, phylogenetic analysis of the genus Petunia, and to resolve the breeding history of garden petunias (Petunia hybrida). We would also be interested in the phylogenetic relationships within all species of the genus Petunia if the sequences of the PolA1 gene could be analyzed on the other 14 taxa.

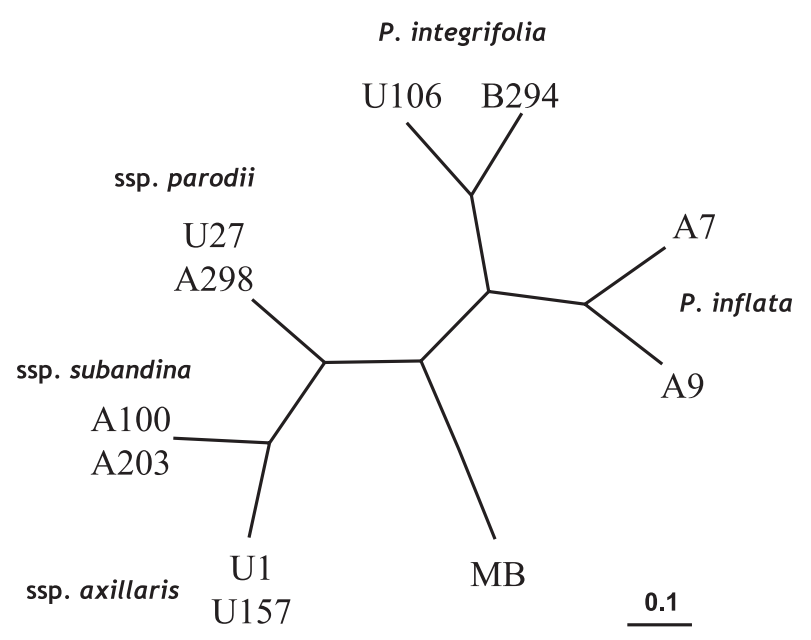

Fig. 3. Phylogenetic tree was constructed using combined sequences of 19th intron and 20th exon in PolA1 gene by DNA maximum likelihood analysis of PHYML. P. inflata (A7, A9), P. integlifolia (U106, B294), P. axillaris subsp. subandina (A100, A203), P. axillaris subsp. axillaris (U1, U157), P. axillaris subsp. parodii (U27, A298), Calibrachoa 'Million Bell' (MB).

\section{Acknowledgements}

We would like to express our sincere thanks to Professor T. Ando (Faculty of Horticulture, Chiba University, Chiba, Japan) for providing original plant materials, and to Associate Professor H. Kokubun (Faculty of Horticulture, Chiba University, Chiba, Japan) for his kind assistance during the course of this research. 


\section{Literature Cited}

Altschul,S.F., W.Gish, W.Miller, E.W.Myers and D.J.Lipman (1990) Basic local alignment search tool. J. Mol. Bio. 215: 403-410.

Ando,T. (1996) Distribution of Petunia axillaris (Solanaceae) and its new subspecies in Agrentina and Bolivia. Acta Phytotax. Geobot. 47: 19-30.

Ando,T., N.Saito, F.Tatsuzawa, T.Kakefuda, K.Yamakage, E.Ohtani, M. Koshi-ishi, Y.Matsusake, H.Kokubun, H.Watanabe, T. Tsukamoto, Y.Ueda, G.Hasimoto, E.Marchesi, K.Asakura, R.Hara and H. Seki (1999) Floral anthocyanins in wild taxa of Petunia (Solanaceae). Biochem. Syst. Ecol. 27: 623-650.

Ando, T., N. Ishikawa, H. Watanabe, H. Kokubun, Y. Yanagisawa, G.Hashimoto, E.Marchesi and E.Suarez (2005) A morphological study of the Petunia integrifolia complex (Solanaceae). Ann. Bot. 96: 887-900.

Cabrera,A.L. (1977) Novedades en las Solanaceas de Entre Rios. Hickenia 1: 79-81.

Cerny, T.A., G.Caetano-Anolles, R.N.Trigiano and T.W.Starman (1996) Molecular phylogeny and DNA amplification fingerprinting of Petunia taxa. Theor. Appl. Genet. 92: 1009-1016.

Ferguson,M.C. and A.M.Ottley (1932) Studies in Petunia. III. A redescription and additional discussion of certain species of Petunia. Am. J. Bot. 19: 385-403.

Fries, R.E. (1911) Die Arten der Gattung Petunia. Kungl. Svenska Vetenskapsakad. Handl. 46: 1-72.

Griesbach,R.J. and R.M.Beck (2000) Molecular heterogeneity of the chalcone synthase intron in Petunia. HortScience 35: $1347-$ 1349 .

Guindon, S. and O.Gascuel (2003) A simple, fast, and accurate algorithm to estimate large phylogenies by maximum likelihood. Sys. Bio. 52: 696-704.

Jussieu,A.L. (1803) Sur le Petunia, genre nouveau de la famille des plantes solanees. Annales du Museum National d'Histoire Naturelle 2: 214-216.

Kabbaj,A., F.Zeboudj, D.Peltier, A.Tagmount, M.Tersac, H.Delieu and A.Berbille (1995) Variation and phylogeny of the ribosomal DNA unit types and 5S DNA in Petunia Jussieu. Gen. Reso. Crop Evol. 42: 311-325.

Kulcheski,F.R., V.C.Muschner, A.P.Lorenz-Lemke, J.R.Stehmann, S.L.Bonatto, F.M.Salzano and L.B.Freitas (2006) Molecular phylogenetic analysis of Petunia Juss. (Solanaceae). Genetica
126: 3-14.

Lassner,M.W., P.Peterson and J.I.Yoder (1989) Simultaneous amplification of multiple DNA fragments by polymerase chain reaction in the analysis of transgenic plants and their progeny. Plant Mol. Biol. Rep. 7: 116-128.

Mishiba,K., T.Ando, M.Mii, H.Watanabe, H.Kokubun, G. Hashimoto and E. Marchesi (2000) Nuclear DNA content as an index character discriminating taxa in the genus Petunia sensu Jussieu (Solanaceae). Ann. Bot. 85: 665-673.

Paxton,J. (1836) Petunia nyctaginiflora violacea. Paxton's Magazine of Botany 2: 173 .

Sang, T. (2002) Utility of low-copy nuclear gene sequences in plant phylogenetics. Critical Reviews in Biochemistry and Molecular Biology 37: 121-147.

Sink, K.C. (1975) Inheritance of three genes for morphological characters in Petunia hybrida in crosses with four Petunia species. Can. J. Genet. Cytol. 17: 67-74.

Smith,L.B. and R.J.Downs (1966) Petunia. In Reitz,P.R. (ed.) Flora Illustrada Catarinense. Solanaceas. Herbário 'Barbosa Rodrigues', Itajai, Santa Catarina, Brazil. pp. 261-291.

Steere,W.C. (1931) Petunia parodii, a new species of the subgenus Pseudonicotiana from Argentina. Pap. Michigan Acad. Sci. Arts Let. 13: 213-215.

Takahashi,H. and I.Nakamura (2005) Phylogenetic relationships of the genus Oryza on the analysis of PolA1 20th exon. Breed. Res. 8 (Suppl. 2): 226 (in Japanese).

Thompson,J.D., D.G.Higgins and T.J.Gibson (1994) CLUSTAL W: Improving the sensitivity of progressive multiple sequence alignment through sequence weighting, position-specific gap penalties and weight matrix choice. Nuc. Aci. Res. 22: 46734680.

Watanabe,H., T.Ando, E. Nishino, H.Kokubun, T.Tsukamoto, G. Hashimoto and E.Marchesi (1999) Three groups of species in Petunia sensu Jussieu (Solanaceae) inferred from the intact seed morphology. Amer. J. Bot. 86: 302-305.

Wijsman,H.J.W. (1982) On the inter-relationship of certain species of Petunia I. Taxonomic notes on the parental species of Petunia hybrida. Acta Bot. Neerl. 31: 477-490.

Wijsman,H.J.W. (1990) On the inter-relationship of certain species of Petunia VI. New names for the species of Calibrachoa formerly included into Petunia (Solanaceae). Acta Bot. Neerl. 39: 101-102. 